\title{
In vitro antioxidant, antitumor and leishmanicidal activity of riparin $A$, an analog of the Amazon alkamides from Aniba riparia (Lauraceae)
}

Éverton José Ferreira de ARAÚJO ${ }^{1,2,3}$, Layana Karine Farias LIMA³, Oskar Almeida SILVA ${ }^{1}$, Luís Mário

REZENDE JÚNIOR ${ }^{2}$, Stanley Juan Chavez GUTIERREZ ${ }^{3}$, Fernando Aécio de Amorim CARVALHO ${ }^{1,4}$, Francisco das Chagas Alves LIMA ${ }^{1,5}$, Cláudia PESSOA ${ }^{6}$, Rivelilson Mendes de FREITAS ${ }^{1,2,3}$ (In Memoriam), Paulo Michel Pinheiro FERREIRA ${ }^{1,7 *}$

\footnotetext{
1 Universidade Federal do Piauí, Programa de Pós-Graduação da Rede Nordeste em Biotecnologia, 64049-550, Teresina, Brasil

2 Universidade Federal do Piauí, Programa de Pós-Graduação em Ciências Farmacêuticas, Laboratório de Pesquisa em Neuroquímica Experimental, 64049-550, Teresina, Brasil

3 Universidade Federal do Piauí, Curso de Farmácia, 64049-550, Teresina, Brasil

${ }^{4}$ Universidade Federal do Piauí, Núcleo de Pesquisa em Plantas Medicinais, Departamento de Bioquímica e Farmacologia, 64049-550, Teresina, Brasil

${ }^{5}$ Universidade Estadual do Piaú, Departamento de Química, 64002-150, Teresina, Brasil

${ }^{6}$ Universidade Federal do Ceará, Departamento de Fisiologia e Farmacologia / Fundação Oswaldo Cruz, 60.430-270, Fortaleza, Brasil

7 Universidade Federal do Piauí, Departamento de Biofísica e Fisiologia, Laboratório de Cancerologia Experimental, 64049-550, Teresina, Brasil

Corresponding author: pmpf@ufpi.edu.br
}

\section{ABSTRACT}

Aniba riparia (Lauraceae) is an important medicinal plant found in the Amazon region and presents alkaloids of the type alkamide known as riparins. Riparin A is structurally represented as the fundamental core of all Amazon riparins. This work aimed to assess the in vitro antioxidant, antitumor and antileishmanial effects of riparin A. Riparin A presented weak antioxidant capacity by tecniques of DPPH• (EC50 of $296.2 \mu \mathrm{g} \mathrm{mL}^{-1}$ ) and ABTS + $\left(\mathrm{EC} 50\right.$ of $450.1 \mu \mathrm{g} \mathrm{mL} \mathrm{m}^{-1}$ ), showed moderate activity against colon carcinoma (HCT-116: IC50 of $21.7 \mu \mathrm{g} \mathrm{mL}^{-1}$ ) and leishmanicidal activity on promastigotes of L. amazonensis $\left(\mathrm{IC}_{50}\right.$ of $307.0 \pm 79.6,193.7 \pm 44.3$ and $81.8 \pm 11.2 \mu \mathrm{g} \mathrm{mL} \mathrm{L}^{-1}$, respectively, after 24, 48 and $72 \mathrm{~h}$ of incubation). Then, in addition to its structural simplicity, riparin A revealed promising biological activities and remarkable in vitro leishmanicidal action, an important result in epidemiological point of view to control leishmaniasis in Brazil, including in the Amazon region.

KEYWORDS: Bioprospecting, Chemoprevention, Cytotoxicity, Antiparasitic drug.

\section{Atividade antioxidante, antitumoral e leishmanicida in vitro da riparina $A$, um análogo das alcamidas amazônicas de Aniba riparia (Lauraceae)}

\section{RESUMO}

Aniba riparia (Lauraceae) é uma importante planta medicinal encontrada na regiáo amazônica que apresenta alcaloides do tipo alcamida e conhecidos como riparinas. Este trabalho teve como objetivo avaliar os efeitos antioxidantes, antitumorais e leishmanicidas in vitro da riparina A. Riparina A apresentou fraca capacidade antioxidante pelas técnicas do DPPH $($ CE50 de 296,2 $\mu \mathrm{g} \mathrm{mL}^{-1}$ ) e ABTS •+ (CE50 de 450,1 $\mu \mathrm{g} \mathrm{mL}^{-1}$ ), mostrou moderada atividade contra carcinoma de cólon (HCT-116: CI50 de 21,7 $\left.\mathrm{ug} \mathrm{mL}^{-1}\right)$ e atividade leishmanicida sobre formas promastigotas de Leishmania amazonensis $\left(\mathrm{CI}_{50}\right.$ de $307,0 \pm$ 79,6; 193,7 \pm 44,3 e 81,8 $\pm 11,2 \mu \mathrm{g} \mathrm{mL} \mathrm{L}^{-1}$, respectivamente, após 24, 48 e $72 \mathrm{~h}$ de incubação). Assim, além de sua simplicidade estrutural, a riparina A revelou atividades biológicas promissoras e significativa ação leishmanicida in vitro, resultado importante diante da relevância epidemiológica para controle da leishmaniose no Brasil, inclusive na região amazônica.

PALAVRAS-CHAVE: Bioprospecção, Quimioprevenção, Citotoxicidade, Droga antiparasitária. 


\section{INTRODUCTION}

Aniba riparia (Nees) Mez is an important medicinal plant belonging to the Lauraceae family. The Lauraceae family stands out both ecologically and economically. Many of its species are used in folk medicine to treat skin lesions, gastric disorders and circulatory problems, and some of them have antiinflammatory and hypoglycemic properties and central effects. The various activities are attributed to alkamide alkaloids, which are known as riparins (Santos et al. 2011). Riparins possess anxiolytic, antidepressant, anticonvulsant, antimicrobial and myorelaxing action. Natural riparins n-benzoyl tyramine (riparin I), n-(-2-hydroxybenzoyl) tyramine (riparin II) and $\mathrm{n}$-(2,6-dihydroxybenzoyl) tyramine (riparin III) have been isolated from an unripe fruit of Aniba riparia, a plant of typical occurrence in the Amazon region, popularly known as "louro" (Catão et al. 2005; Teixeira et al. 2013).

In addition to the naturally occurring molecules in $A$. riparia, using the Schotten-Bauman reaction, Gutierrez et al. (2005) obtained synthetic analogues called riparins A, B, C, D, $\mathrm{E}$ and $\mathrm{F}$ (Figure 1). Thus, the amount of molecules that can be tested regarding their pharmacological and toxicological properties have increased, since these substances share the same fundamental structure of natural riparins, without requiring the exploitation of the Brazilian flora.

Therefore, riparin $\mathrm{A}$, represented as the core structure of all Amazonian riparins, emerges as a promising molecule. Tests regarding its antioxidant and myorelaxing effects in animal models indicated that riparin A has neuroprotective capacity, without reducing the muscle tone of rodents (Nunes et al. 2014; 2015). Riparin A has also recently demonstrated antiinflammatory potential in acute inflammation models, in which it reduced inflammatory response through inhibition of cellular events, neutrophils migration modulation and inhibition of proinflammatory cytokines (TNF- $\alpha$ and IL-1 $\beta$ ) production.

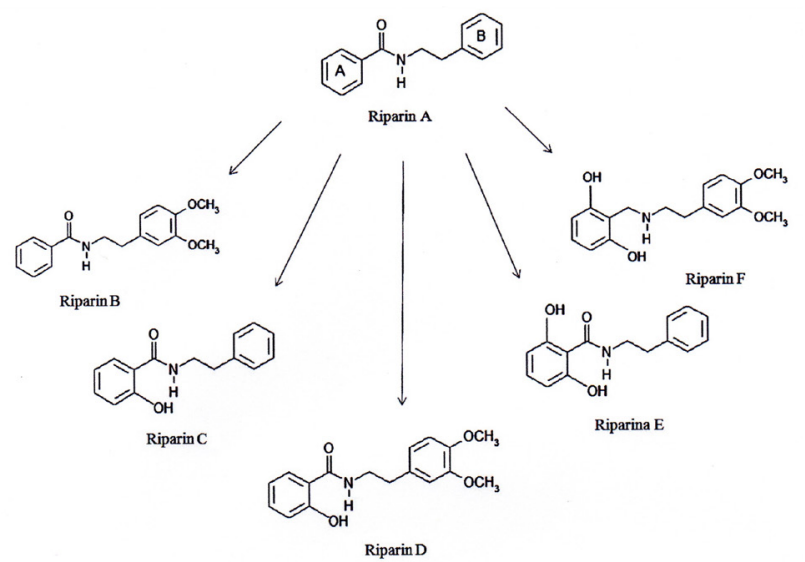

Figure 1. Molecular structure of the synthetic riparinas (B, C, D, E and F) based on the fundamental structure of the natural riparin $A$.
These events are often triggered by parasites, microorganisms and local circulatory changes (Silva et al. 2015). Then, this study aimed to assess the in vitro the antioxidant, antitumor and antileishmanial effects of riparin A.

\section{MATERIALS AND METHODS}

\section{Sample collection}

Riparin A was obtained following the Schoten-Bauman reaction, through the mixture of $0.41 \mathrm{~mL}$ acyl chloride and $0.89 \mathrm{~mL}$ 2-phenylethylamine with triethylamine, followed by magnetic stirring and purification by column chromatography, as described by Gutierrez et al. (2005) and Nunes et al. (2015).

\section{Antioxidant Activity Evaluation by DPPH $\bullet$ and ABTS•+ Methods}

For in vitro antioxidant evaluation, stock solutions of riparin A, $\mathrm{DPPH}^{*}(9.8 \mathrm{mM}), \mathrm{ABTS}^{*+}(7 \mathrm{mM})$ and vitamin $C$ standard $(20 \mathrm{mM})$ were prepared in $4 \%$ DMSO (dimethylsulfoxide). All solutions had a final concentration of $4 \%$ DMSO. In order to determine the antioxidant activity by ABTS assay, the methodology described by Re et al. (1999) was used. The $\mathrm{DPPH}^{*}$ method was based in Blois (1958) and adapted by Brand-Williams et al. (1995). Following dilution, concentrations of 24, 120, 240, 480 and $1200 \mu \mathrm{g} \mathrm{mL}^{-1}$ of riparin were obtained. Vitamin C (Vit. C) was used as positive control $\left(176 \mu \mathrm{g} \mathrm{mL}^{-1}\right)$.

The $50 \%$ effective concentration $\left(\mathrm{EC}_{50}\right)$ of riparin $\mathrm{A}$ was determined spectrophotometrically (T80+ UV/VIS Spectrometer, PG Instruments Ltd', Leicestershire, UK) at 517 $\mathrm{nm}$ for $\mathrm{DPPH}^{\cdot}$ and in $734 \mathrm{~nm}$ for $\mathrm{ABTS}^{*}, 30$ minutes after the reaction started. Antioxidant evaluation was performed in triplicate and absorbance values were converted to the inhibition percentage (I) of radicals using the equation of Reanmongkol et al. (1994): I (\%) = [(Abs.control - Abs.sample) x 100]/Abs.control, where Abs.control is the $\mathrm{DPPH}^{*}$ or $\mathrm{ABTS}^{+*}$ solution initial absorbance and Abs.sample is the reaction mixture absorbance (DPPH* ${ }^{*}$ or $\mathrm{ABTS}^{*+}$ and sample).

\section{Cytotoxic evaluation}

Cytotoxicity evaluation was conducted using the MTT assay (Mosmann 1983) in three human tumor lines: HCT116 (colon cancer), OVCAR-8 (ovarian) and SF-295 (glioblastoma). Cell lines were grown in plastic flasks using the RPMI 1640 culture medium supplemented with $10 \%$ fetal bovine serum and $1 \%$ antibiotics (penicillin/streptomycin). Cells were incubated at $37^{\circ} \mathrm{C}$ with an atmosphere of $5 \% \mathrm{CO}_{2}$ and $95 \%$ humidity $\left(\mathrm{CO}_{2}\right.$ Incubator, Shel Lab, Cornelius, USA). Afterwards, cells were observed every $24 \mathrm{~h}$ in relation to cell growth and contamination control in an inverted microscope (Nikon Inverted Microscope, City Labs, Tokyo, Japan) and, when necessary, cells were subcultured on fresh culture medium. 
Cells were plated in 96-well plates (0.3-0.7 x $10^{5}$ cells/ well) and incubated in order to allow cell adhesion. After $24 \mathrm{~h}$, riparin $A$ was added to each well in increasing concentrations $\left(0.004-50 \mu \mathrm{g} \mathrm{mL}^{-1}\right)$. Cells of the negative control, positive control and those treated with riparin were exposed to the same DMSO percentage (0.1\%) (Ferreira et al. 2014). After $69 \mathrm{~h}$, plates were centrifuged at $1,000 \mathrm{~g}$ per $15 \mathrm{~min}$, the supernatant was aspirated and $200 \mu \mathrm{L}$ of $10 \%$ MTT solution was added in RPMI 1640. The plate was placed in an incubator at $5 \% \mathrm{CO}_{2}$ for additional $3 \mathrm{~h}$. Then, plates were centrifuged again at $1,000 \mathrm{~g}$ per $15 \mathrm{~min}$, the supernatant was aspirated and its precipitate was resuspended in pure DMSO. Afterwards, it was stirred for about $10 \mathrm{~min}$, until formazan crystals were completely dissolute. The chemotherapeutic doxorubicin (Sigma Aldrich, USA) was used as positive control $\left(0.005-5.0 \mu \mathrm{g} \mathrm{mL}^{-1}\right)$. Plates were read in a plate spectrophotometer at the wavelength of $595 \mathrm{~nm}$ (DTX 880 Multimode Detector, Beckman Coulter, Harbor Boulevard, Fullerton, USA).

\section{Leishmanicidal activity avaluation}

For the leishmanicidal test, L. amazonensis strains grown in Schneider's medium (Sigma Aldrich, USA), supplemented with 10\% fetal bovine serum (Sigma Aldrich, USA), penicillin and streptomycin were used. Promastigote forms in their logarithmic growth phase were distributed into 96-well plates for cell culture, in the amount of $1 \times 10^{6}$ leishmanias/ well. Starting from a riparin A stock solution, serial dilutions in the range of $1: 2\left(25-800 \mu \mathrm{g} \mathrm{mL}^{-1}\right)$ were carried out in a Schneider's medium. Plates were incubated at $26{ }^{\circ} \mathrm{C}$ temperature in biochemical oxygen demand (BOD) incubator and observed at 24,48 and $72 \mathrm{~h}$ of exposure to the substance, analyzing leishmania growth and viability in a Neubauer chamber. Amphotericin B was used as positive control (40 $\mu \mathrm{g} \mathrm{mL} \mathrm{L}^{-1}$ in $4 \% \mathrm{DMSO}$ ).

\section{Statistical analysis}

$\mathrm{EC}_{50}$ and $\mathrm{IC}_{50}$ values and their confidence intervals of $95 \%$ were obtained by linear regression. Results shown as mean $[ \pm$ standard error of the mean (S.E.M.)], from two independent experiments, were assessed using ANOVA followed by Newman-Keuls test (GraphPad Prism 5.0, Intuitive Software for Science, San Diego, CA, USA), considering $p<0.05$.

\section{RESULTS}

\section{Antioxidant activity}

Riparin A decreased $\mathrm{DPPH}^{\bullet}$ (2,2-diphenyl-1-picrylhydrazyl) levels, regardless of its concentration, in $27.7 \pm$ $1.3 ; 26.5 \pm 0.2 ; 27.3 \pm 0.2 ; 30.4 \pm 1.9$ and $34.0 \pm 0.1 \%$, in the concentrations of 24, 120, 240, 480 and $1200 \mu \mathrm{g} \mathrm{mL}^{-1}$, respectively, with $\mathrm{CE}_{50}$ of $296.2 \mu \mathrm{g} \mathrm{mL}-1$. Meanwhile, vitamin C showed inhibition of $61.3 \pm 0.9 \%(p<0.05)$ (Figure $2 \mathrm{~A}$ ).

Similarly, riparin A caused $\mathrm{ABTS}^{\circ}{ }^{+}$radical inhibition of $33.2 \pm 1.3 ; 33.3 \pm 1.0 ; 34.5 \pm 0.2 ; 35.0 \pm 0.2$ and $35.3 \pm$ $1.2 \%$ in concentrations of $24,120,240,480$ and $1200 \mu \mathrm{g}$ $\mathrm{mL}^{-1}$, respectively, and $\mathrm{EC}_{50}$ value of $450.1 \mu \mathrm{g} \mathrm{mL}-1$. Vitamin $\mathrm{C}$ reduced the radical $93.5 \pm 1.6 \%(p<0.05)$ (Figure $2 \mathrm{~B}$ ).

\section{Cytotoxic activity}

In this study, riparin A showed moderate antiproliferative activity against colon carcinoma (HCT-116) tumor cells, with an $\mathrm{IC}_{50}$ of 21.7 (19.8 to 23.8) $\mu \mathrm{g} \mathrm{mL} \mathrm{mL}^{-1}$ (Table 1).

In relation to the leishmanicidal potential, riparin $\mathrm{A}$ acted on $L$. amazonensis promastigotes with $\mathrm{IC}_{50}$ values of $307.0 \pm$ 79.6; $193.7 \pm 44.3$; and $81.8 \pm 11.2 \mu \mathrm{g} \mathrm{mL} \mathrm{m}^{-1}$ after 24,48 and $72 \mathrm{~h}$ of incubation, respectively $(p<0.05)$ (Figure 3 ).

\section{DISCUSSION}

Innovative molecules endowed with biological activity, that can be obtained at an affordable cost, with low toxicity and in a sustainable way, have been the focus of the pharmaceutical industry and academic institutions in recent years, in order to show alternatives to processes based on predatory extraction of active substances of natural species (Nunes et al. 2013; Cardoso et al. 2015; Ferreira et al. 2015). These bioactive substances have been highlighted, especially in research for the treatment or prevention of chronic diseases associated with oxidative stress, such as cancer or infectious diseases. The latter, although neglected, are responsible for high morbidity

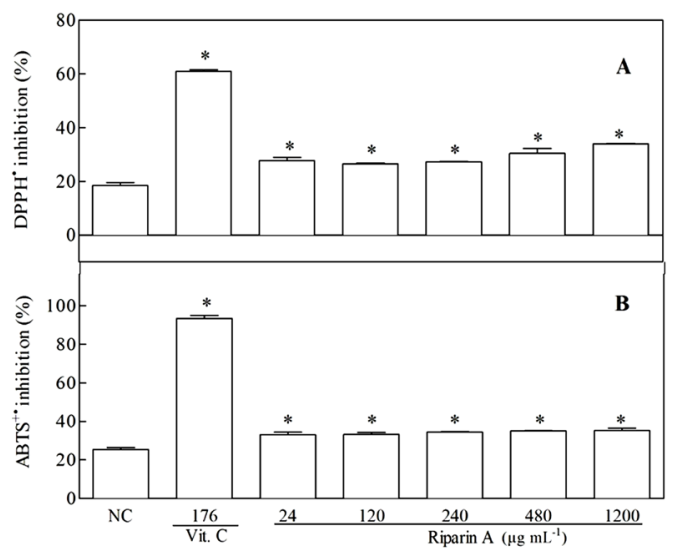

Figure 2. Effects of riparin $A$ on the DPPH $\bullet(A)$ and $A B T S \bullet+(B)$ reduction. The results are expressed as average of the percentage of inhibition \pm standard error of the mean (S.E.M.) of independent experiments $(n=2)$. Negative control (NC) was treated with the solution used for diluting the tested substance. Vitamin C (Vit. C) was used as positive control (176 $\mathrm{\mu g}$ $\left.\mathrm{mL}^{-1}\right)$. ${ }^{\star} \mathrm{p}<0.05$ when compared to the negative control by ANOVA followed by Student-Neuman-Keuls test. 


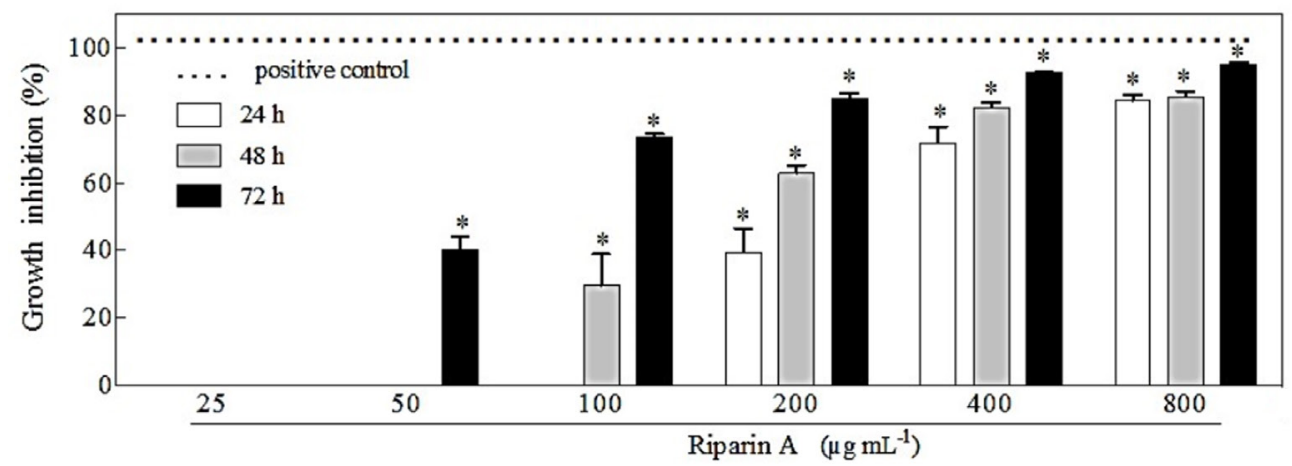

Figure 3. Cytotoxicity of riparin A on Leishmania amazonensis promastigotes after 24,48 and $72 \mathrm{~h}$ exposure. The results are expressed as average of the percentage of inhibition \pm standard error of the mean (S.E.M.) of independent experiments $(n=2)$. Amphotericin B was used as positive control $\left(40 \mu \mathrm{g} \mathrm{mL}{ }^{-1}\right)$. ${ }^{\star} p<0.05$ when compared to the negative control by ANOVA followed by Student-Neuman-Keuls test.

Table 1. In vitro cytotoxic activity of riparin A on cancer lines determined by MTT assay after $72 \mathrm{~h}$ of incubation.

\begin{tabular}{lccc}
\hline \multirow{2}{*}{ Sample } & & $\mathrm{IC}_{50}(\mu \mathrm{g} \mathrm{mL})^{-1}$ & SF-295 \\
\cline { 2 - 4 } Riparin A & HCT-116 & OVCAR-8 & $>50$ \\
Doxorubicin & $21.7(19.8-23.8)$ & $>50$ & $0.2(0.2-0.3)$ \\
\hline
\end{tabular}

* Data are presented as $\mathrm{IC}_{50}$ values and 95\% confidence intervals for colon (HCT-116), ovarian (OVCAR-8) and glioblastoma (SF-295) tumor lines. Doxorubicin was used as positive control. Experiments were performed in duplicate.

and mortality rates in developing countries (Alves et al. 2010;

Oliveira et al. 2012; Farias et al. 2013).

The oxidation phenomenon naturally occurs in cellular processes as part of the biochemical reaction mechanism, in cellular energy production, in intercellular signaling and phagocytosis. However, excessive oxidation may cause damage to cells, resulting in the evolution or aggravation of diseases (Alam et al. 2012). The $\mathrm{DPPH}^{*}$ method has been used in many substance antioxidant evaluation studies based on the capacity of these substances to sequester the radical (Sharma and Bhat 2009; Nascimento et al. 2011; Farias et al., 2013). In this study, riparin $\mathrm{A}$ reduced $\mathrm{DPPH}^{\circ}$ and $\mathrm{ABTS}^{\circ}$ levels, proving to be a molecule with chemopreventive potential.

The $\mathrm{ABTS}^{*+}$ radical, which is a chromophore, soluble and stable compound produced from the 2,2-azino-bis(3ethylbenzothiazoline)-6-sulfonic precursor, when captured by potentially antioxidant molecules, causes absorbance decrease and subsequent reduction in the concentration of the tested sample (Villaño et al. 2004; Sucupira et al. 2012). The riparin A molecule, due to having potential electron donors only in the nitrogen and oxygen and few potential acceptor in the hydrogen atoms, proved to be a substance endowed with limited antioxidant capacity.

There are records showing that essential oils of Piper divaricatum species from the Brazilian Amazon are rich in mono and sesquiterpenes, or phenylpropanoids. A study conducted by Silva et al. (2010) showed that the oil extracted from the species was effective in inhibiting the DPPH ${ }^{*}$ radical formation in up to $74 \%$, with a $\mathrm{CE}_{50}$ value of $16.2 \pm 1.9 \mu \mathrm{g}$ $\mathrm{mL}^{-1}$. On the other hand, Santana et al. (2014) reported that the Mikania glomerata leaf ethanol extract was able to reduce $\mathrm{DPPH}^{*}$ and $\mathrm{ABTS}^{\bullet+}$ levels $\left(\mathrm{CE}_{50}\right.$ values of $138.91 \mu \mathrm{g} \mathrm{mL} \mathrm{m}^{-1}$ and $175.68 \mu \mathrm{g} \mathrm{mL}^{-1}$, respectively).

The group of this study previously showed that synthetic riparins (A-F) have antiproliferative potential (Nunes et al. 2014). In this study, cytotoxic activity was confirmed in other cancer cell lines, with selective effect on colon carcinoma. In addition, it was found that riparins $\mathrm{C}, \mathrm{D}, \mathrm{E}$ and $\mathrm{F}$ showed cytotoxic activity in laryngeal (HEP-2) and lung (NCIH292) carcinoma lines and in leukemia cells (HL-60), with $\mathrm{IC}_{50}$ values ranging from 1.9 to $11.4 \mu \mathrm{g} \mathrm{mL}-1$. Moreover, cell proliferation inhibition capacity was higher than $90 \%$ on colon adenocarcinoma cells (HT-29), confirming the most recent studies by the group of this study, in which the riparin A showed cytotoxic activity against colon carcinoma. It is believed that synthetic riparins cytotoxic activity is related to the substituents of their aromatic rings (Shayne et al. 2007). It is possible that hydroxyl presence and methoxy groups absence increases the antiproliferative activity of riparins $\mathrm{C}, \mathrm{D}$ and $\mathrm{E}$. Similarly, the fact that the fundamental structure (represented by riparin $\mathrm{A}$ ), which is devoid of substituents, showed no relevant activity, endorses the hypothesis that hydroxyl insertion in lateral rings is associated with antitumor activity. 
Like cancer, protozoa are responsible for millions of disease cases with varied features worldwide, although such diseases mainly affect countries with medium to low economic and social development levels, besides areas with sanitation, environmental education and health program deficits (Rodrigues et al. 2013). In Central and South American countries, including the perimeter represented by the Amazon forest, as well as in Africa, South Asia and Middle East, leishmaniasis has large impact on individuals and communities. Thus, researches for novel molecules with anti-parasitic efficacy are stimulated, against, for example, Leishmania braziliensis and Leishmania amazonensis, which are the most prevalent species in the maintenance of the leishmaniasis epidemiological chain in Brazil (Dorval et al. 2006; Teles et al. 2014). Therefore, riparin A showed leishmanicidal activity against $L$. amazonensis promastigotes within $72 \mathrm{~h}$ of incubation. In a similar study, Silva et al. (2014) showed that the methanol extract and a hexane fraction of the Lacistema pubescens Mart. Amazonian species had $\mathrm{IC}_{50}$ values of 3.9 and $3.5 \mu \mathrm{g} \mathrm{mL}-1$ against $L$. amazonensis. The results obtained in this study are considerable, since riparin $\mathrm{A}$ showed lower $\mathrm{IC}_{50}$ values against $L$. amazonensis than the $\mathrm{N}$-methyl-glucamine compound ( 120.3 to $400.3 \mu \mathrm{g} \mathrm{mL}^{-1}$ ) (Costa-Filho et al. 2008), which is used as standard antimony drug for cutaneous leishmaniasis treatment. N-methyl-glucamine causes several side effects, such as arthralgia, myalgia, appetite loss, nausea, vomiting, epigastric pain, heartburn, abdominal pain, rash, fever, weakness, headache, dizziness, palpitations, insomnia, nervousness, edema and acute renal failure, in addition to being inappropriate for the treatment of pregnant women and patients with pulmonary tuberculosis, malaria, heart diseases, kidney diseases, liver diseases and Chagas disease, requiring rigorous and constant assessment and monitoring in clinical use. Associated with prominent side effects, antimonial drugs are also capable of inducing parasitic resistance (Rath et al. 2003; Rodrigues et al. 2006; Pelissari et al. 2011).

\section{CONCLUSION}

The N-phenyl benzamide compound, or riparin A, due to its structural simplicity, is easy to be obtained, it has shown promising biological activities and has significant in vitro leishmanicidal action. These findings are important because of the epidemiological importance of leishmaniasis in Brazil, including in the Amazon region. Given this bioactive potential, studies aiming at elucidating the pharmacological mechanism and pharmacophore group(s) of riparins in nanocarrier systems are being conducted, in order to enhance their bioavailability and their therapeutic activities.

\section{ACKNOWLEDGEMENTS}

Thanks to the Brazilian Federal Agency CAPES (Coordenação de Aperfeiçoamento de Pessoal de Nivel Superior) for the scholarships and scientific development incentive (process 407575/2013-8) and Priscila Murolo for her help with editing of the manuscript.

\section{REFERENCES}

Alam, N.; Bristi, N.J.; Rafiquzzaman. 2012. Review on in vivo and in vitro methods evaluation of antioxidant activity. Saudi Pharmaceutical Journal, 21: 143-152.

Alves, C.Q.; David, J.M.; David, J.P.; Bahia, M.V.; Aguiar, R.M. 2010. Métodos para determinação de atividade antioxidante in vitro em substratos orgânicos. Química Nova, 33: 2202-2210.

Blois, M.S. 1958. Antioxidant determination by the use of a stable free radical. Nature, 181: 199-1200.

Brand-Williams, W.; Cuvelier, M.E.; Berset, C. 1995. Use of a free radical method to evaluate antioxidant activity. Food Science and Technology, 28: 25-30.

Catão, R.M.R.; Gutierrez, S.J.C.; Barbosa-Filho, J.M. ; Lima, E. O. ; Pereira, M.S.V.; Arruda, T.A.; Antunes, R.M.P. 2005. Avaliação da atividade antimicrobiana de riparinas sobre cepas de Staphylococcus aureus e Escherichia coli multirresistentes. Revista Brasileira de Análises Clinicas, 37: 247-249.

Cardoso, M.V.O.; Moreira, D.R.M.; Bezerra Filho, G.O.; Cavalcanti, S.M.T.; Coêlho, L.C.D.; Espindola, J.W.P.; Gonzalez, L.R.; Rabello, M.M.; Hernandez, M.Z; Ferreira, P.M.P.; et al. 2015. Design, synthesis and structure-activity relationship of phthalimides endowed with dual antiproliferative and immunomodulatory activities. European Journal of Medicinal Chemistry, 96: 491-503.

Costa-Filho, A.V.; Lucas, I.C.; Sampaio, R.N.R. 2008. Comparative study between oral miltefosine and parenteral $\mathrm{N}$-metil glucamine antimoniate for the treatment of experimental leishmaniasis caused Leishmania (Leishmania) amazonenses. Revista da Sociedade Brasileira de Medicina Tropical, 41: 424-427.

Dorval, M.E.M.C.; Oshiro, E.T.; Cupollilo, E.; Castro, A.C.C.; Alves, T.P. 2006. Ocorrência de leishmaniose tegumentar americana no Estado do Mato Grosso do Sul associada à infecção por Leishmania (Leishmania) amazonensis. Revista da Sociedade Brasileira de Medicina Tropical, 39: 43-46.

Farias D.F.; Souza T.M.; Viana M.P.; Soares, B.M.; Cunha, A.P.; Vasconcelos, I.M.; Ricardo, N.M.P.S.; Ferreira, P.M.P.; Melo, V.M.M; Carvalho, A.F.U. 2013. Antibacterial, antioxidant, and anticholinesterase activities of plant seed extracts from Brazilian semiarid region. BioMed Research International, 2013: 1-9.

Ferreira, P.M.P.; Militão, G.C.G.; Lima, D.J.B.; Costa, N.D.J.; Machado, K.C.; Santos, A.G.; Cavalheiro, A.J.; Bolzani, V.S.; Silva, D.H.S.; Pessoa, C. 2014. Morphological and biochemical alterations activated by antitumor clerodane diterpenes. Chemico-Biological Interactions, 222C: 112-125.

Ferreira, P.M.P.; Costa, P.M.; Costa, A.M.; Lima, D.J.B.; Drumond, R.R.; Silva, J.N. et al. 2015. Cytotoxic and toxicological effects of 
phthalimide derivatives on tumor and normal murine cells. Anais da Academia Brasileira de Ciências, 87: 313-330.

Gutierrez, S.J.C.; Barbosa-Filho, J.M.; Claudino, F.S.; Silva, B.A.; Souza, M.F.V.; Almeida, R.N.; Camara, C.A. 2005. N-Benzoyltryptamine derivatives with relaxant activity in guinea-pig ileum. Il Farmaco (Pavia), 60: 475-477.

Mosmann, T. 1983. Rapid colorimetric assay for cellular growth and survival: application to proliferation and cytotoxicity assays. Journal of Immunological Methods, 65: 55-63.

Nascimento, J.C.; Lage, L.F.O.; Camargos, C.R.D.; Amaral, J.C.; Costa, L.M.; Sousa, A.N.; Oliveira, F.Q. 2011. Determinação da atividade antioxidante pelo método DPPH e doseamento de flavonóides totais em extratos de folhas da Bauhinia variegata L. Revista Brasileira de Farmácia, 92: 327-332.

Nunes, G.B.L.; Costa, L.M.; Gutierrez, S.J.C.; Nunes, L.C.C.; Freitas, R.M. 2013. Prospecção científica e tecnológica da Aniba riparia (Nees) Mez (Lauraceae). Cadernos de Prospecção, 6: 447-458.

Nunes, G.B.L.; Policarpo, P. L.; Costa, L.M.; Silva, T.G.; Militão, G.C.G.; Câmara, C.A.; Barbosa-Filho, J.M.; Gutierrez, S.J.C.; Islam, M.T.; Freitas, R.M. 2014. In vitro antioxidant and cytotoxic activity of some synthetic riparin-derived compounds. Molecules, 19: 4595-4607.

Nunes, G.B.L.; Costa, L.M.; Gutierrez, S.J.C.; Satyal, P.; Freitas, R.M. 2015. Behavioral tests and oxidative stress evaluation in mitochondria isolated from the brain and liver of mice treated with riparin A. Life Sciences, 121: 57-64.

Oliveira, V.M.; Vila nova, M.X.; Assis, C.R.D. 2012. Doenças tropicais negligenciadas na regiāo Nordeste do Brasil. Scire Salutis, 2: 29-48.

Pelissari, D.M.; Cechinel, M.P.; Sousa-gomes, M.L.; Júnior, F.E.F.L. 2011. Tratamento da leishmaniose visceral e leishmaniose tegumentar americana no Brasil. Epidemiologia e Serviços de Saúde, 20: $107-110$.

Rath, S.; Trivelin, L.A.; Imbrunito, T.R.; Tomazela, D.M.; Jesús, M.N.; Marzal, P.C.; Andrade-Júnior, H.F.; Tempone, A.G. 2003. Antimoniais empregados no tratamento da leishmaniose: Estado da Arte. Química Nova, 26: 550-555.

Reanmongkol, W.; Matsumoto, K.; Watanabe, H.; Subhadhirasakul, S.; Sakai, S.I. 1994. Antinociceptive and antipyretic effects of alkaloids extracted from the stem bark of Hunteria zeylanica. Biological and Pharmaceutical Bulletin, 17: 1345-1350.

Re, R.; Pellegrini, N.; Proteggente, A.; Pannala, A.; Yang, M.; Rice-Evans C. 1999. ntioxidant activity applying an improved ABTS radical cation decolorization assay. Free Radical Biology and Medicine, 26: 1231-1237.

Rodrigues, K.A.F.; Amorim, L.V.; Oliveira, J.M.G.; Dias, C.N.; Moraes, D.F.C.; Andrade, E.H.A.; Maia, J.G.S.; Carneiro, S.M.P.; Carvalho, F.A.A. 2013. Eugenia uniflora L. essential oil as a potential anti-leishmania agent: effects on Leishmania amazonensis and possible mechanisms of action. Evidence-Based Complementary and Alternative Medicine, 2013: 1-10.

Rodrigues, A.; Hueb, M.; Santos, T.A.R.R.; Fontes, C.J.F. 2006. Fatores associados ao insucesso do tratamento da leishmaniose cutânea com antimoniato de meglumina. Revista da Sociedade Brasileira de Medicina Tropical, 39: 139-145.
Santana, L.C.L.; Brito, M.R.M.; Oliveira, G.L.S.; Citó, A.M.G.L.; Alves, C.Q.; David, J.P.; David, J.M.; Freitas, R.M. 2014. Mikania glomerata: phytochemical, pharmacological and neurohemical study. Evidence-based Complementary and Alternative Medicine, 2014: 1-11.

Santos, S.G. dos; Queiroga, K.F.; de Oliveira, A.M.; Tavares, J.F.; Gutierrez, S.J.; Diniz, M. de F.; Barbosa-Filho, J.M.; da Silva, M.S. 2011. Blood matrix effects for male and female Wistar rats in simultaneous HPLC-UV determination of riparin I and III from Aniba riparia (Nees) Mez. (Lauraceae). Talanta, 86: 233-240.

Sharma, O.P., Bhat, T.K. 2009. DPPH antioxidant assay revisited. Food Chemistry, 113: 1202-1205.

Shayne, M.; Culakova, E.; Poniewierski, M.S.; Wolff, D.; Dale, D.C.; Crawford, J.; Lyman, G.H. 2007. Dose intensity and hematologic toxicity in older cancer patients receiving systemic chemotherapy. Cancer, 110: 1611-1620.

Silva, J.K. da; Andrade, E.H.; Guimarães, E.F.; Maia, J.G. 2010. Essential oil composition, antioxidant capacity and antifungal activity of Piper divaricatum. Natural Product Communications, 5: 477-480.

Silva, J.M. da; Antinarelli, L.M.; Pinto, N.C.; Coimbra, E.S., Souza-Fagundes, E.M.; Ribeiro, A.; Scio, E. 2014. HPLC-DAD analysis, antileishmanial, antiproliferative, and antibacterial activities of Lacistema pubescens: an Amazonian medicinal plant. BioMed Research International, 2014: 1-7.

Silva, R.O.; Damasceno, S.R.; Silva, I.S.; Silva, V.G.; Brito, C.F.; Teixeira, A.E; et al. 2015. Riparin A, a compound from Aniba riparia, attenuate the inflammatory response by modulation of neutrophil migration. Chemico-Biological Interactions, 229: 55-63

Sucupira, N.R.; Silva, A.B.; Pereira, G.; Costa, J.N. 2012. Métodos para a determinaçấo da atividade antioxidante de frutos. Unopar Cientifica Ciências Biológicas e da Saúde, 14: 263-269.

Teixeira, C.P.; Melo, C.T.; Araújo, F.L.; Carvalho, A.M.; Silva, M.I.; Barbosa-Filho, J.M.; Macedo D.S.; Viana G.S.B.; Sousa, F.C. 2013. Antidepressant-like effect of riparin II from Aniba riparia in mice: evidence for the involvement of the monoaminergic system. Fundamental and Clinical Pharmacology, 27: 129-137.

Teles, E.J.C.; Soares, D.C.; Gasparetto, D.; Veiga, N.; Fontelles, M.J.P.; Garcez, L.M. 2014. Leishmaniose visceral no município minerário de Barcarena, Estado do Pará, Brasil: evolução de 2004 a 2008 e bases para a vigilância epidemiológica. Revista Pan-Amazônica de Saúde, 5: 21-27.

Villaño, D.; Fernández-Pachón, M.S.; Troncoso, A.M.; García-Parrilla, M.C. 2004. The antioxidant activity of wines determined by ABTS method: influence of sample dilution and time. Talanta, 64: 501-509.

Recebido 21/11/2015

Aceito em 16/02/2016 